\title{
Optimization and Production of Hyaluronidase by Streptococcus mitis MTCC 2695
}

\author{
Narayanan Mahesh ${ }^{1 *}$, Srinivasan Balakumar ${ }^{1}$, R Parkavi ${ }^{1}$, Arunadevi Ayyadurai ${ }^{1}$ and Rangarajan Vivek²
}

${ }^{1}$ Department of Chemistry and Biosciences, Srinivasa Ramanujan Centre, SASTRA University, Kumbakonam - 612001, India

${ }^{2}$ Department of Biotechnology, Indian Institute of Technology, Kharagpur-721 302, India

\begin{abstract}
Hyaluronidase was produced by submerged fermentation from Streptococcus mitis. The possibility of using Streptococcus mitis for enzyme production has been recently investigated. In this study, the physical and nutritional parameters were optimized to improve the production of hyaluronidase by Streptococcus mitis and it was accessed. Maximum production of hyaluronidase was obtained when $5 \%$ starch supplemented as carbon source achieved by employing $(98.7 \mathrm{U} / \mathrm{ml})$ and followed by ammonium chloride $(140.4 \mathrm{U} / \mathrm{ml})$ incubation period about 48 hours showed $(108.9 \mathrm{U} / \mathrm{ml})$ and temperature at $37^{\circ} \mathrm{C}$ showed $(179.9 \mathrm{U} / \mathrm{ml})$. The maximum enzyme yield on $\mathrm{pH} 4$ is $(110.7 \mathrm{U} / \mathrm{ml})$. The production of hyaluronidase by means of immobilized Streptococcus mitis was evaluated and a maximum production was obtained with the medium was inoculated with 100 beads $(591 \mathrm{U} / \mathrm{ml})$ which was more than that of mobilized cells.
\end{abstract}

Keywords: Hyaluronidase; Streptococcus mitis; Submerged fermentation; Hyaluronan; Immobilization

\section{Introduction}

Hyaluronidase is an enzyme which hydrolyses hyaluronic acid, a high molecular weight non-sulfated linear glycosaminoglycan, which is composed of repeating disaccharide units, D-glucuronic acid and $\mathrm{N}$ acetyl glucosamine [1]. Hyaluronidase is naturally found in mammals, insects, leaches and bacteria [2]. Hyaluronidase can be produced by submerged fermentation from Streptococcus mitis [3-5]. It is a valuable enzyme because it can acts as an adjuvant, which accelerates and increases the absorption and dispersion of injected drugs [6].

The hyaluronidases from different sources vary in their molecular weight, based on substrate specificity, $\mathrm{pH}$ optima and catalytic mechanism [6]. Although widely distributed in nature, hyaluronidases are not well characterized and are a group of neglected enzymes owing to their difficult purification and lack of scientific interest over a large period of time [7]. However in recent years there is growing interest in the possible role of hyaluronan and hyaluronidase in numerous biological processes. Hyaluronidase was also useful in the direct reduction of hyaluronic acid that was improperly placed during injection [8-10].

The hyaluronate lyases, isolated from various microorganisms as e.g., strain of Clostridium, Streptococcus, Micrococcus, Streptomyces, Staphylococcus, Peptostreptococcus and Propionibacterium differ in substrate specificity [11-18].

\section{Application of hyaluronidase}

For many years, hyaluronidases, especially BTH preparation are widely used in many fields like orthopedic, surgery, ophthalmology, internal medicine, oncology, dermatology and gynecology [19].

The most common application is in ophthalmic surgery, in which it is used in combination with local anesthetics [20]. Sperm hyaluronidase is involved as a key play in successful fertilization in most mammalian, including human [10,21]. Hyaluronidase is also used for extravasation of hyperosmolar solution. Usually a $0.2 \mathrm{ml}$ of the drugs is injected around the area of extravasation. Some bacteria, such as Staphylococcus aureus, Streptococcus pyogenes and Clostridium perfringens [19,22-26] produce hyaluronidase as a means for greater mobility through the body's tissues [27] and as an antigenic distinguish that prevents their being recognized by phagocytes of the immune system $[11,28]$. Hyaluronidase has been investigated as an additive to chemotherapeutic drugs for augmentation of the anticancer effect [29]. There is evidence that hyaluronidase may have intrinsic anticancer effects and can suppress tumor progression [8]. It has been used therapeutically due to their capacity to reduce biological fluid viscosity, increase vascular permeability and render tissues more accessible to certain drugs [30].

\section{Materials and Methods}

\section{Procurement of microorganism}

Streptococcus mitis MTCC 2695 were procured from Chandigarh and maintained on Mitis salivarius agar base medium slant. Sub culture was done at subsequent intervals.

\section{Substrate for hyaluronidase production}

The suitable substrate for hyaluronidase is hyaluronic acid which was procured from Sigma Aldrich (USA). The best substrate achieved by this step was fixed for subsequent experiments.

\section{Submerged fermentation}

Submerged fermentation was conducted in $250 \mathrm{ml}$ flask containing $100 \mathrm{ml}$ of the modified nutrient broth. $25 \mu \mathrm{l}$ of hyaluronic acid was added in the medium. After sterilization by autoclaving, flasks were cooled and inoculated with a $5 \% \mathrm{v} / \mathrm{v}$ inoculums level and incubated at $37^{\circ} \mathrm{C}$ on a rotary shaker at $150 \mathrm{rpm}$ for 48 hours [31].

*Corresponding author: Narayanan Mahesh, Department of Chemistry and Biosciences, Srinivasa Ramanujan Centre, SASTRA University, Kumbakonam 612001, Tel: 91-4352426823; Fax: 91-4352402460; E-mail: magi.mbbt@gmail.com

Received December 05, 2011; Accepted January 26, 2012; Published February 04,2012

Citation: Mahesh N, Balakumar S, Parkavi R, Ayyadurai A, Vivek R (2012) Optimization and Production of Hyaluronidase by Streptococcus mitis MTCC 2695 . J Biomol Res Ther 1:101. doi:10.4172/2167-7956.1000101

Copyright: (C) 2012 Mahesh N, et al. This is an open-access article distributed under the terms of the Creative Commons Attribution License, which permits unrestricted use, distribution, and reproduction in any medium, provided the original author and source are credited. 
Citation: Mahesh N, Balakumar S, Parkavi R, Ayyadurai A, Vivek R (2012) Optimization and Production of Hyaluronidase by Streptococcus mitis MTCC 2695. J Biomol Res Ther 1:101. doi:10.4172/2167-7956.1000101

Page 2 of 4

\section{Extraction and recovery of enzymes}

The well grown culture was centrifuged at $8000 \mathrm{~g}$, for 30 minutes at $4^{\circ} \mathrm{C}$. The supernatant, used as crude enzyme was assayed for hyaluronidase activity.

\section{Analytical method}

Enzyme assay: The method of assay is Dorfmans in which the enzymatic reduction in turbidity was determined by monitoring spectrophotometrically, at $600 \mathrm{~nm}$ and kept at $37^{\circ} \mathrm{C}$. $1 \mathrm{ml}$ of hyaluronic acid was taken in a test tube. $1 \mathrm{ml}$ of enzyme sample solution was added in the presence of $0.05 \mathrm{M}$ sodium phosphate buffer with $0.05 \mathrm{M}$ Nacl. This mixture was incubated for 30 minutes at $37^{\circ} \mathrm{C}$. To the above incubated mixture, $2.5 \mathrm{ml}$ of acidified protein solution $(1 \% \mathrm{w} / \mathrm{v})$ bovine serum albumin fraction - V (BSA) in $0.5 \mathrm{M}$ sodium acetate buffer was added. Then incubated at $37^{\circ} \mathrm{C}$ for 10 minutes and reduction in turbidity was read by measuring the absorbance at $600 \mathrm{~nm}$ [32].

\section{Optimization of media for hyaluronidase production by Streptococcus mitis}

Carbon source: Effect of addition of carbon source for maximal enzyme production was evaluated using various sugars which include maltose, fructose, lactose; starch and cellulose were studied by adding at a concentration of $0.5 \mathrm{mg} / \mathrm{ml}$ to the basal production medium. Then hyaluronidase assay were performed as described earlier [32].

Nitrogen source: Effect of addition nitrogen source on hyaluronidase production was evaluated using ammonium acetate, ammonium nitrate, sodium nitrite, urea and ammonium chloride at a concentration of $0.25 \mathrm{~g}$ each and hyaluronidase assay were done [32].

Temperature of the medium for hyaluronidase production: Suitable temperature of the medium that support maximal enzyme production was determined by keeping production conical flask at the temperature ranges as $20^{\circ}, 37^{\circ}, 45^{\circ}, 50^{\circ}$ and $60^{\circ} \mathrm{C}$. Then hyaluronidase assay were completed [32].

Initial $\mathrm{pH}$ of the medium for hyaluronidase production: Suitable $\mathrm{pH}$ of the medium that support maximal enzyme production was determined by adjusting the $\mathrm{pH}$ to various levels ranges as $\mathrm{pH} 4,5,6,8$ and 9 using $1 \mathrm{~N} \mathrm{HCl}$ and $1 \mathrm{~N} \mathrm{NaOH}$. Further hyaluronidase assay were done [32].

Incubation period of the medium for hyaluronidase production: Suitable incubation period of the medium that support maximal enzyme production was determined by adjusting the duration to various levels ranges from 24, 48, 72, 96 and 120 hours. Then hyaluronidase assay were performed [32].

\section{Effect of immobilized cell}

Cells were harvested after 48 hours centrifugation at $6000 \mathrm{xg}$ for 15 minutes, $1 \mathrm{mg}$ (dry cell weight) suspended in $2 \mathrm{ml}$ of sterile distilled water and added to $2 \%(\mathrm{w} / \mathrm{v})$ sterile sodium alginate solution to achieve the required cell/alginate ratio. The obtained mixture was then extruded drop wise through a $5 \mathrm{ml}$ syringe into a gently stirred $2 \%(\mathrm{w} / \mathrm{v}) \mathrm{CaCl}_{2}$ solution from about $5 \mathrm{~cm}$ height and hardened in this solution for 1 hour. The beads were washed twice with sterile distilled water before being used as inoculum for hyaluronidase. Suitable cell immobilization of the medium that support maximal enzyme production was determined by adjusting the beads to various levels ranges from 50, 100, 150, 200 and 250 for 24 and 48 hours. Further hyaluronidase assay were performed as described earlier [32].

\section{Results and Discussion}

\section{Effect of various carbon sources on hyaluronidase production}

Various carbon sources were added to the fermentation medium for the production of hyaluronidase at $0.05 \%$ concentration. The sugars were tested glucose, sucrose, mannitol, dextrin, dextrose, starch, and sodium alginate. All these sugars were good enough for hyaluronidase production, but especially sucrose $(245 \mathrm{U} / \mathrm{ml})$ yields slightly higher amount of hyaluronidase [9].

A pathological isolate Streptococcus equi SED 9 was used for production of an extracellular enzyme hyaluronidase by using various carbon sources. Among them dextrose enhanced production and it was found to be $271 \mathrm{U} / \mathrm{ml}[4,25]$.

Various carbon sources such as maltose, fructose, starch, lactose and cellulose were used in present research. From this carbon source of starch gives maximum yields of hyaluronidase $(98.7 \mathrm{U} / \mathrm{ml})$ when compared to other sources (Figure 1).

\section{Effect of various nitrogen sources}

The effect of various nitrogen sources such as ammonium acetate, ammonium bicarbonate, ammonium chloride and ammonium sulphate. The maximum enzyme production was suggested that ammonium chloride $(225 \mathrm{U} / \mathrm{ml})$ gave the highest enzyme production [9]

The experiments were carried out for the production of various nitrogen sources on hyaluronidase production by using Streptococcus equi SED 9. Among them ammonium sulfate influenced the maximum yield of enzyme production and it was found to be $258 \mathrm{U} / \mathrm{ml}$ [4].

In the present research studied with various nitrogen sources were added to the fermentation medium for the production of hyaluronidase at $0.25 \mathrm{~g}$. The nitrogen sources were tested ammonium chloride, ammonium acetate, urea, sodium nitrite and ammonium nitrate. Maximum yield of hyaluronidase was obtained in the order of ammonium chloride $(140.4 \mathrm{U} / \mathrm{ml})$. From this result concluded that the nitrogen source variation changes due to the nutritional factors and environmental factors (Figure 2).

\section{Effect of various temperatures}

The effect of various temperatures such as $20^{\circ}, 37^{\circ}, 45^{\circ}, 50^{\circ}$ and $60^{\circ} \mathrm{C}$ and maximum yield $(179 \mathrm{U} / \mathrm{ml})$ was produced at $37^{\circ} \mathrm{C}$ [9].

The experiments were carried out for the production of various temperatures on hyaluronidase production by using Streptococcus equi

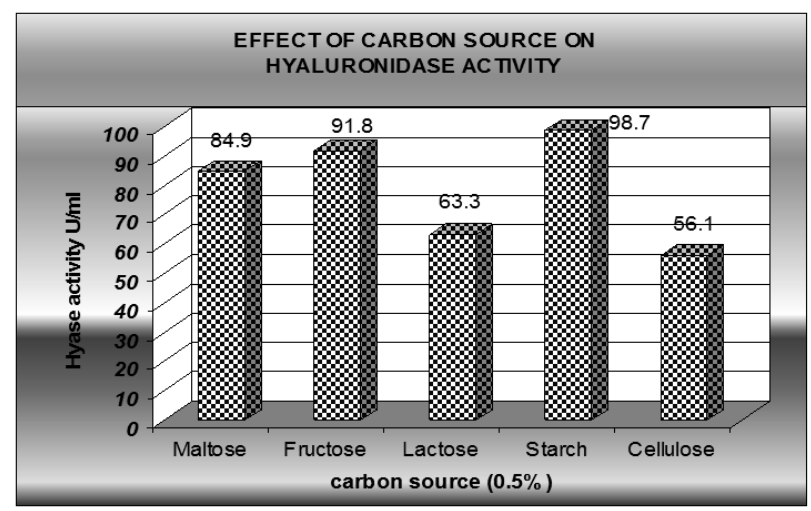

Figure 1: Effect of carbon sources on hyaluronidase production using Streptococcus mitis. 
Citation: Mahesh N, Balakumar S, Parkavi R, Ayyadurai A, Vivek R (2012) Optimization and Production of Hyaluronidase by Streptococcus mitis MTCC 2695. J Biomol Res Ther 1:101. doi:10.4172/2167-7956.1000101

SED 9. Among them $37^{\circ} \mathrm{C}$ influenced the maximum yield of enzyme production and it was found to be $167 \mathrm{U} / \mathrm{ml}$ [24].

In the present research studied with fermentation by varied temperature of the medium $20,37,45,50$ and $60^{\circ} \mathrm{C}$. The maximum yield is $(174.9 \mathrm{U} / \mathrm{ml})$ was produced at $37^{\circ} \mathrm{C}$. Similarly in our investigation proves that $37^{\circ} \mathrm{C}$ optimal or maximal production (Figure 3 ).

\section{Effect of various $\mathrm{pHs}$}

The effect of $\mathrm{pH}$ on hyaluronidase production was studied by varied the $\mathrm{pH}$ of the medium from 4-9. The production increased to 181 $\mathrm{U} / \mathrm{ml}$ at $\mathrm{pH}$ 5.8. There was a gradual decrease in enzyme field from $\mathrm{pH}$ range from 5.8 to 7.2 above and below this range activity decreased sharply [9].

The experiments were carried out for the production of various $\mathrm{pH}$ on hyaluronidase production by using Streptococcus equi SED 9. Among them $\mathrm{pH} 5.5$ influenced the maximum yield of enzyme production and it was found to be $165 \mathrm{U} / \mathrm{ml}[4,24]$.

In the present research studied at various $\mathrm{pHs}$ such as $4,5,6,8$ and 9. The maximum yield of hyaluronidase production up to $(110.7 \mathrm{U} / \mathrm{ml})$ produced at $\mathrm{pH} 4$. These increased yields support the growth of organism and increase metabolic rate of organism. Due to the rapid metabolic process on the cell increase the product directly. This concludes that $\mathrm{pH} 4$, supports organism metabolic rates actively. The rate of product was high when compared to Sahoo et al. (Figure 4) [4].

\section{EFFECT OF NITROGEN SOURCE}

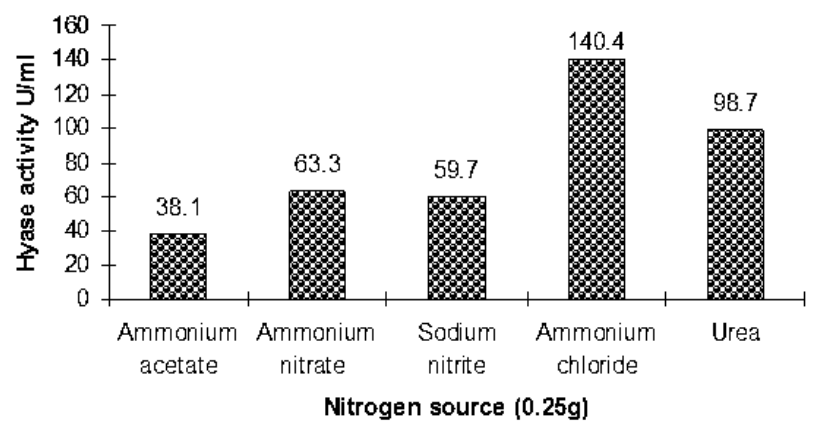

Figure 2: Effect of various nitrogen sources on hyaluronidase production using Streptococcus mitis.

\section{EFFECT OF TEMPERATURE}

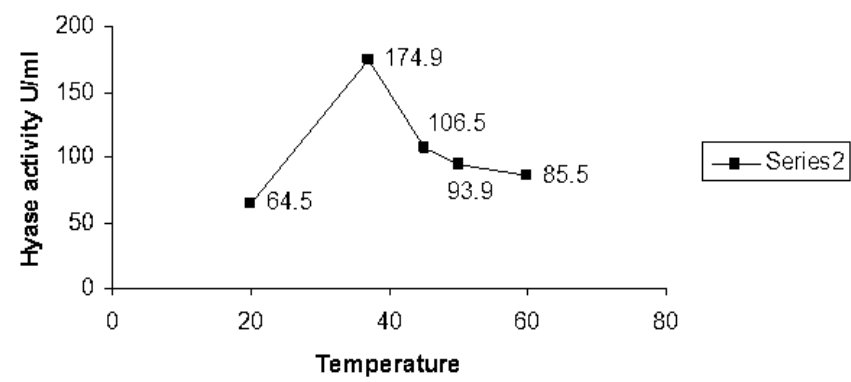

Figure 3: Effect of various temperatures on hyaluronidase production using Streptococcus mitis.

\section{Effect of various incubation periods}

The effect of fermentation process, and the incubation period of medium varied from 12-96 hours. Among them 48 hours enhanced the maximum yield of enzyme production and it was found to be 181 $\mathrm{U} / \mathrm{ml}[9]$.

In the present research studied with fermentation of incubation period is $24,48,72,96,120$ hours and maximum yield $(108.9 \mathrm{U} / \mathrm{ml})$ was produced within 48 hours. From, this result in concluded that the incubation period variation changes the metabolic pathways of organism to regulate the enzyme activity. When compared to Sahoo et al. report, it is slightly decreased but other parameters support for the maximum production (Figure 5) [24].

\section{Effect of immobilized cells}

In the present research studied with fermentation by varied number of beads of the medium such as 50,100, 150, 200 and 250 for 24 and 48 hours. The maximum number of 100 bead yield is $(591 \mathrm{U} / \mathrm{ml})$ was produced for 48 hours. It is first report on immobilization that gives more amount of enzyme production (Figure 6).

\section{Conclusion}

The present research showed that higher levels of hyaluronidase produced at increasing agitation values and the time of fermentation with the maximum values are produced with its satisfactory yields. The production of hyaluronidase were influenced by the carbon source like starch, maltose, fructose, lactose and cellulose, nitrogen source like ammonium chloride, ammonium nitrate, sodium nitrite, ammonium

\section{EFFECT OF pH ON HYALURONIDASE ACTIVITY}

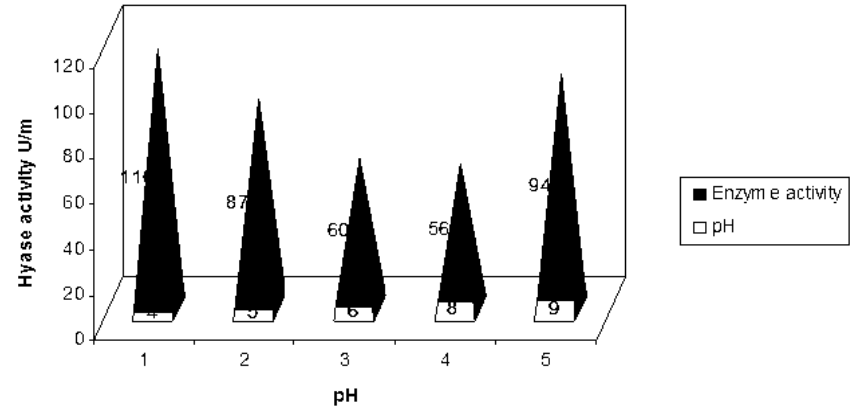

Figure 4: Effect of various $\mathrm{pH}$ on hyaluronidase production using Streptococcus mitis.

EFFECT OF INCUBATION PERIOD

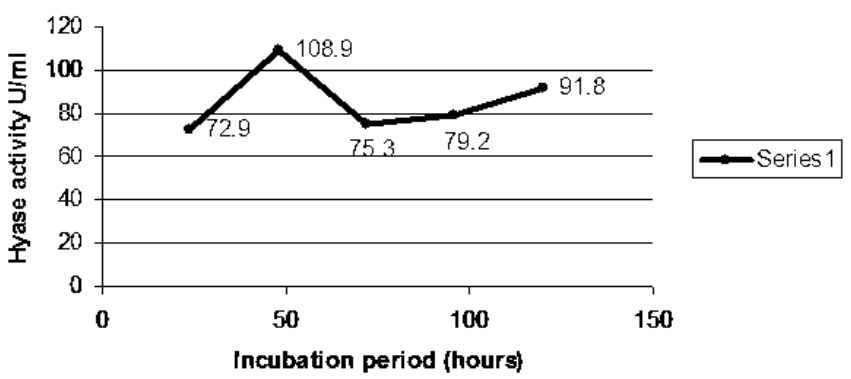

Figure 5: Effect of various incubation periods on hyaluronidase production using Streptococcus mitis. 
Citation: Mahesh N, Balakumar S, Parkavi R, Ayyadurai A, Vivek R (2012) Optimization and Production of Hyaluronidase by Streptococcus mitis MTCC 2695. J Biomol Res Ther 1:101. doi:10.4172/2167-7956.1000101

EFFECT OF IMMOBILILIZED CELLS

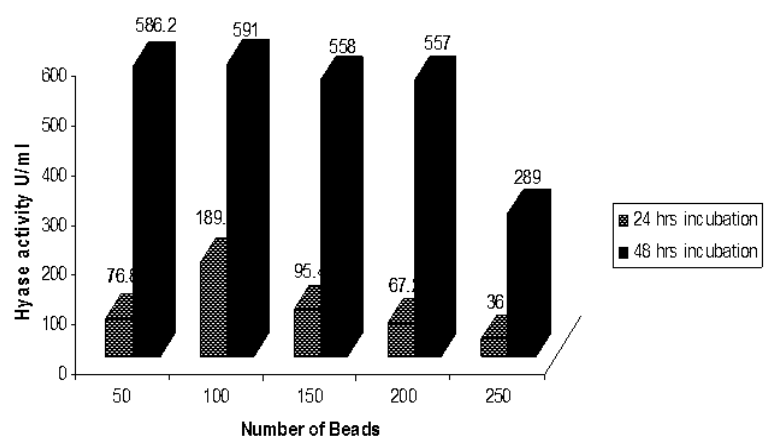

Figure 6: Effect of immobilized cells on hyaluronidase production using Streptococcus mitis.

acetate and urea, $\mathrm{pH}-4,5,6,8$ and 9 , temperature such as $20-60^{\circ} \mathrm{C}$ and incubation period such as $24-120$ hours. Then the effect of immobilized cells in different beads such as $50,100,150,200$, and 250 incubated for 24 and 48 hours. Among all these, high amount hyaluronidase was produced by optimized source yield starch $(98.7 \mathrm{U} / \mathrm{ml})$, ammonium chloride (140.4 U/ml), pH $4(110.7 \mathrm{U} / \mathrm{ml})$, temperature $37^{\circ} \mathrm{C}(174.9 \mathrm{U} /$ $\mathrm{ml}$ ). The strain of Streptococcus mitis was evaluated and maximum production was obtained when the medium was inoculated with 100 beads ( $591 \mathrm{U} / \mathrm{ml}$ ) for 48 hour which was more than that of immobilized cells. From the hyaluronidase production medium were measured. This present research concluded that hyaluronidase production gives boon for the medical and pharmaceutical fields.

\section{References}

1. Assis CM, Gandra RF, Gambale W, Shimizu MT, Paula CR (2003) Biosynthesis of chondroitinase and hyaluronidase by different strains of Paracoccidioides brasiliensis. J Med Microbiol 52: 479-481.

2. Bertolami CN, Donoff RB (1982) Identification, Characterization, and Partial Purification of Mammalian Skin Wound Hyaluronidase. J Invest Dermatol 79: $417-421$.

3. Lorina PL, Lisanti VF, Chauncey HH (1954) The production of beta-glucuronidase and hyaluronidase by Streptococcus mitis. Oral Surg Oral Med Oral Pathol 7: 998-1010.

4. Sahoo S, Panda PK, Mishra SR, Nayak A, Dash SK, et al. (2008) Optimization of physical and nutritional parameters for hyaluronidase production by Streptococcus mitis. Indian J pharm Sci 70: 661-664.

5. Unsworth PF (1989) Hyaluronidase production in Streptococcus milleri in relation to infection. J Clin Pathol 42: 506-510.

6. Yingprasertchai S, Bunyasrisawat S, Ratanabanangkoon K (2003) Hyaluronidase inhibitors (sodium cromoglycate and sodium auro-thiomalate) reduce the local tissue damage and prolong the survival time of mice injected with Naja kaowthia and calloselasma rhodostoma venoms. Toxicon 42: 635-646.

7. Machiah DK, Girish KS, Gowda VT (2006) A glycoprotein from a fold medicinal plant Withania sommifera inhibits hyaluronidase activity of snake venoms. Comparative Biochem Physiol 143: 158-161.

8. Brody HJ (2005) Use of Hyaluronidase in the Treatment of Granulomatous Hyaluronic Acid Reactions or Unwanted Hyaluronic Acid Misplacement. Dermatol Surg 31: 893-897.

9. Rogers HJ (1954) The Influence of Hydrolysates of Hyaluronate upon Hyaluronidase Production by Micro-organisms. Biochem J 40: 583-588.

10. Isman F, Kucur M, Tanriverdi T, Kacira T, Sanus GZ, et al. (2008) Serum hyaluronidase levels in patients with aneurismal subarachnoid haemorrhage. Singapore med J 49: 405-409.

11. Akhtar S, Bhakuni V (2004) Streptococcus pneumoniae hyaluronate lyase: An overview. Curr Sci 86: 285-295.
12. Carter GR, Chengappa MM (1980) Hyaluronidase production by type B Pasteurella multocida from cases of hemorrhagic septicemia. J Clin Microbiol 11 94-96.

13. Morey SS, Kiran KM, Gadag JRG (2006) Purification and properties of hyaluronidase from Palamneus gravimanus (Indian black scorpion) venom. Toxicon 47: 188-195.

14. Oettl M, Hoechstetter J, Asen I, Bernhardt G, Buschauer A (2003) Comparative characterization of bovine testicular hyaluronidase and a hyaluronate lyase from Streptococcus agalactiae in pharmaceutical preparation. Eur J Pharm Sci 18: $267-277$.

15. Puhvel SM, Reisner RM (1972) The production of hyaluronidase (hyaluronate lyase) by Corynebacterium acnes. J Invest Dermatol 58: 66-70.

16. Songlin LI, Taylors KB, Kelly SJ, Jedrzejas MJ (2001) Vitamin C inhibits the enzymatic activity of Streptococcus pneumoniae hyaluronate lyase. J Boil Chem 276: 15125-15130.

17. Tam YC, Chan EC (1985) Purification and characterization of hyaluronidase from oral Peptostreptococcus species. Infect Immun 47: 508-513.

18. Tam YC, Chan EC (1983) Phase variation of hyaluronidase producing Peptostreptococci associated with periodontal disease. J Dent Res 62: 1009-1012.

19. Maclennan AP (1956) The production of capsules, hyaluronic acid and hyaluronidase by group A and group C Streptococci. J Gen Microbiol 14: 134-142.

20. VanTeeffelen JW, Dekker S, Fokkema DS, Siebes M, Vink H, et al. (2005) Hyaluronidase treatment of coronary glycocalyx increase reactive hyperemia but not adenosine hyperemia in dog hearts. Am J physiol Heart Circ Physiol 289: 2508-2513.

21. Tanyiblizi S, Bozkurt T (2002) Effect of progesterone and testosterone on the hyaluronidase activities and sperm characteristics of sheep. Turk J Vet Anim Sci 26: 1137-1143.

22. Matsushita O, Okabe A (2001) Clostridial hydrolytic enzymes degrading extra cellular components. Toxicon 39: 1769-1780.

23. Rautela SG, Abramson C (1973) Crystallization and partial characterization of Staphylococcus aureus hyaluronate lyase. Arch Biochem Biophys 158: 687 694.

24. Sahoo S, Panda PK, Mishra SR, Nayak A, Ellaiah P, et al. (2007) Optimization of some physical and nutritional parameters for the production of hyaluronidase by Streptococcus equi SED 9. Acta Pol Pharm 64: 517-522.

25. Wayne LH, Walton SL (2000) Hyaluronidase of gram positive bacteria. FEMS Microbial Lett 183: 201-207.

26. Zakaite V, Bizculevicius GA (2000) Acceleration of hyaluronidase production in the course of batch cultivation of Clostridium perfringens can be achieved with bacteriolytic enzyme. Lett Appl Microbiol 30: 203-206.

27. Kucur M, Karadag B, Isman FK, Ataev Y, Duman D, et al. (2009) Plasma hyaluronidase activity as an indicator of atherosclerosis in patients with coronary artery disease. Bratisl Lek Listy 110: 21-26.

28. Kjems E, Perch B, Henrichsen J (1980) Serotypes of group B Streptococci and their relation to hyaluronidase production and hydrolysis of salicin. J Clin Microbiol 2: 111-113.

29. Sumantran VN, Kulkarni AA, Harsulkar A, Wele A, Koppikar SJ, et al. (2007) Hyaluronidase and collegenase inhibitory activities of the herbal formulation Triphala guggulu. J Biosci 32: 755-761.

30. Bitencourt CS, Pereira PA, Ramos SG, Sampaio SV, Arantes EC, et al. (2011) Hyaluronidase recruits mesenchymal-like cells to the lung and ameliorates fibrosis. Fibrogenesis Tissue Repair 4: 3

31. Bautista J, Chico E, Machado A (1986) Effects of discharged fraction in repeated batch culture for hyaluronate lyase production. J Fermentation Techno 64: 419-424.

32. Dorfman A (1955) Methods in Enzymology. Vol 1,166. Ed by Colowick SP and Kaplan NO. Academic Press, New York.

33. Feng L, Gao R, Gopalakrishnakone $\mathrm{P}$ (2008) Isolation and characterization of a hyaluronidase from the venom of Chinese red scorpion Buthus martensi. Comp Biochem Physiol C Toxicol Pharmacol 148: 250-257.

34. Da C B Gouveia Al, da Silveira RB, Nader HB, Dietrich CP, Gremski W, et al (2005) Identification and partial characterisation of hyaluronidases in Lonomia obliqua venom. Toxicon 45: 403-410. 